\title{
correspondence
}

\section{Good and bad Nobel prizes}

SIR,--The Soviet authorities and mass-media are distinguishing between 'good' and 'bad' Nobel prizes. A Nobel prize is a good one and means great and deserved recognition for the USSR, if it is awarded to an obedient and loyal Soviet intellectual: to the writer Sjolokhov, to the physicists Basov and Prokhorov, to the chemist Semjonov or the economist Kantorovich.

The Nobel prize is a bad one and is a provocation of western imperialists and international reaction, if it is awarded to some of the Soviet writers or scientists, who are on the 'banned' index; say Boris Pasternak, Alexander Solzhenitsyn or Andreii Sakharov. Pjotr Kapitsa's recent Nobel prize for physics is considered good by Soviet authorities and mass-media.

Professor Kapitsa is no doubt a great and famous scientist. He was awarded the Nobel prize for a discovery he made 40 years ago in Moscow with equipment which had been sent to him by his professor, Ernest Rutherford, from Cambridge. But is this year's Nobel prize really a good one for the Soviet Union? Does Pjotr Kapitsa really belong to the obedient and loyal Soviet intellectuals?

The facts of his life suggest the opposite. The young Soviet physicist came to Cambridge in 1921 and in a few years became Rutherford's most respected collaborator and expected successor in the Cavendish Laboratory. In 1934 Kapitsa left for a vacation in the Soviet Union and unexpectedly was prevented by Soviet government from returning to Cambridge.

The Soviet government offered him a new institute in Moscow without any financial and administrative restrictions.

Rutherford had been trying very hard to get his collaborator back, but when he finally saw the vanity of his attempts, he finally decided to make a beautiful gesture: he sent the equipment of Kapitsa's recently-built Mond laboratory to Moscow. Kapitsa had just completed the equipment before his departure on vacation.

Kapitsa had his institute in Moscow, an important position in the Soviet acaderny of sciences, and a considerable influence in the government

when, in 1939, another of the future Nobel laureates and his close friend Lev Landau had been arrested. Kapitsa came to the Kremlin and presented an ultimatum: if Landau was not released, Kapitsa would leave his institute and stop his work. This was a risky step, but the Soviet government needed Kapitsa. Landau was released and his life saved.

In spite of all this Kapitsa was himself a privileged prisoner. Until the late fifties he was not allowed to travel abroad, his contacts with forcign scientists were restricted, and his correspondence of ten confiscated. Kapitsa became a prisoner in his country house at Nikolina Gora in 1945, when he fell out with Stalin over the problem of Soviet nuclear weapons. $\mathrm{He}$ was released from prison only after Stalin's death and only then was able to resume his directorship in the Institute of Physical Problems.
Kapitsa never hid his critical attitude to the Soviet reality, nor his sympathy with those who openly oppose this reality. "How many roubles would our finance ministry release to Rembrandt for the brushes, how much for the canvas and how much for the colours?" says Kapitsa, chiding administrative restrictions confining Soviet science. "On 20 February 1956 an instruction was issued, according to which all directors of academic institutes must present a plan of every single working day for the approval of the academy. But I, for example, cannot plan every single working day, say when $I$ will be sitting in the laboratory and when in my studio-this depends on how our investigations will proceed ..."

Very sharply, and often, Kapitsa criticised the backwardness of Soviet science, its low productivity. In 1965 the USSR and USA had approximately the same number of scientists, but the USA did about one-third of world science, and USSR only one-sixth. "Therefore, no matter how sad it may sound, we have to admit that the productivity of our scientists is two times lower than that of Americans."

Andreii Sakharov is a good friend of Kapitsa, and so are many other Soviet dissidents. Kapitsa was one of the initiators of the public protest which helped to release Soviet biologist Zhores Medvedev from psychiatric prison. His signature was among the few tens demanding the abolition of the death penalty in the USSR. And his villa in the institute park is a frequent meeting place for dissident Soviet intellectuals. The atmosphere inside is stimulating: in Kapitsa's studio hangs a photograph of Solzhenicyn, with his handwritten dedication.

When the Soviet sculptor Ernst Neizvestnyj was expelled from the USSR in 1974. Kapitsa gave a farewell party for him in his house. In the presence of many guests he made a toast, in which he said: "I have to admit that I envy you a little bit. You are young and you will live to the time when you could come back to Moscow. And you will walk on the Solzhenitsyn square, and on Andreii Sakharov prospect, and the street where you will have your atelier will bear your name. But I am already old and will hardly live to see it

Eighty-four years' old academician Kapitsa may really not live long enough to see such changes in USSR. But when they finally come, nobody will denv his merits.

This year's Nobel prize for P jotr Kapitsa is, therefore, not quite a 'good' prize for the Soviet Union. But is more than a highlv deserved prize for an old professor.

Name and address withheld by request

\section{Heraclitus Revisited}

Sir.-You may be interested in these lines stimulated by the review of Erwin Chargaff's new book (Nature 276, 133; 1978):

I'll tell thee everything I can:

There's little to relate.

I met an old, embitter'd man
Bemoaning his sad fate.

"Who are you, aged man?" I said, "And what is your pet peeve?"

His answer trickled through my head Like water through a sieve.

He said "I met a fervid pair Who built a model crude The younger one had lengthy hair And both of them were rude.

They claimed that they were out to find What makes genetics tick

And when I call the scene to mind The mem'ry makes me sick."

But $I$ was thinking of a plan To write a grant request And if the funding once began I'd count myself well-blest.

So, having no reply to give To what the old man said I cried "Come tell me why you grieve" And thumped him on the head.

He said "The times are bestial The world has gone to hell.

My culture is celestial In science I excel.

Of Mozart's symphonies and themes I know the form and keys.

I dream the most exalted dreams Of any Viennese."

But I was thinking of a way To cut him down to size

By noting what he had to say Was something less than wise.

And then I wondered if these lines Would capture his attention

Because his musings show some signs Of scanty comprehension.

And so if e'er by chance 1 put My fingers into glue

Or madly squeeze a right-hand foot Into a left-hand shoe

Or if I drop upon my toe

A very heavy weight

I weep, for it reminds me so

of that old man 1 used to know

Who seems distracted with his woe,

Who mumbles of the long-ago

As if his mouth were full of dough Bemoaning his sad fate.

The Wight Night THOMAS H. JUKES

University of California,

Berkeley, USA

\section{Homo erectus}

SIR,-I was very pleased to see that due recognition was given to Homo eructus in the item on East Javan hominids (28 September, page 306 ).

Few, indeed no, previous commentators have given this hominoidal form sufficient weight, although his more commonly used name gives a clue to his place in taxonomy: just a breath away from Pe-King Man must come Bel-Ching Man.

His undoubted place as a direct ancestor of $H$. sapiens sapiens is attested by $H$. erectus' easily identified descendants in any group of humans today.

However, I have been greatly puzzled over how his patronymic attribute has been deduced from skeletal evidence.

London, UK N. R. LANDON 